\title{
Analisis potensi sabut kelapa serta strategi penggunaanya sebagai bahan baku pakan ternak ruminansia
}

\author{
Mochamad Denta Risman Muzaki 1, ${ }^{\text {, Sunarso }}{ }^{2}$, Agus Setiadi ${ }^{2}$ \\ ${ }^{1}$ Mahasiswa S2 Peternakan Universitas Diponegoro, Semarang, 50275 \\ ${ }^{2}$ Dosen Fakultas Peternakan dan Pertanian Universitas Diponegoro, Semarang, 50275 \\ *Correspondence: denta29@gmail.com
}

Received: January $6^{\text {th }}, 2020$; Accepted: September 28 ${ }^{\text {th }}, 2020$; Published online: November $26^{\text {th }}, 2020$

Abstrak

Tujuan: Tujuan dari penelitian mengkaji dan menganalisis potensi serta strategi penggunaan sabut kelapa sebagai bahan pakan pada complete feed dan konsentrat. Manfaat penelitian ini diharapkan dapat memberikan informasi kepada peternak atau perusahaan pakan ternak ruminansia dalam pemanfaatan limbah sabut kelapa sebagai campuran pada complete feed dan konsentrat. Lokasi penelitian berada di wilayah Kabupaten Batang, Kabupaten Jepara, Kabupaten Pati dan Kabupaten Rembang.

Metode: Metode yang digunakan dalam penelitian ini adalah metode survei. Data yang dikumpulkan berupa data primer didapat langsung dari petani kelapa, pedagang buah kelapa, setiap wilayah diambil sebanyak 10 responden. Data sekunder didapat dari Badan Pusat Statistik dan Dinas Perkebunan Kabupaten Batang, Kabupaten Jepara, Kabupaten Pati dan Kabupaten Rembang. Data yang sudah diperoleh diolah secara deskriptif analisis. Analisis Data menggunakan Analisis Locationt Quotient (LQ), Analisis SWOT dan Analisis Trend untuk memprediksi ketersediaan lahan dan produksi buah kelapa.

Hasil: Hasil dari penelitian menunjukkan bahwa penggunaan limbah sabut kelapa sebagai pakan memiliki potensi yang dapat dikembangkan menggunakan strategi (S-O), Strategi (S-T), Strategi (WO) dan Srategi (W-T) pada analisis SWOT. Pengembangan lahan berdasarkan analisis Locationt Quotient (LQ) sebagai basis yaitu berada di Kabupaten Rembang, Pati dan Jepara. Produksi limbah sabut kelapa berdasarkan BK, PK dan TDN secara keseluruhan yaitu 9.537; 383.29 dan 2.678,4 ton/tahun dan untuk daya dukung limbah sabut kelapa secara keseluruhan berdasarkan BK, PK dan TDN yaitu 31.794; 944,32 dan 8.926 ST/tahun.

Kesimpulan: Kesimpulan dari penelitian yaitu peninjauan dalam produksi dan sediaan lahan dalam peningkatan tanaman kelapa menggunakan analisis Trend yang nantinya berpotensi menyediakan bahan baku yaitu berada pada Kabupaten Rembang.

Kata Kunci: Potensi Kelapa; Complete feed; Daya Dukung Limbah Sabut Kelapa

\section{Abstract}

Objective: The purpose of the study is to assess and analyze the potential and strategies for using coconut coir as feed ingredients in complete feed and concentrates. The research are expected to provide information to ruminant farmers or animal feed companies in the utilization of coconut coir 
waste as a mixture of complete feeds and concentrates. The research location is in the district Batang, Jepara, Pati and Rembang.

Methods: The method used in this study is a survey method. The data collected in the form of primary data were obtained directly from coconut farmers, coconut traders, each region was taken as many as 10 respondents. Secondary data obtained from the local government administration. The data obtained was processed descriptively analysis. Data analyzed uses Locationt Quotient Analysis (LQ), SWOT Analysis and Trend Analysis to predict land availability and coconut production.

Results: The results of the study indicate that the use of coconut fiber waste as feed has potential that can be developed using a strategy in the SWOT analysis, in land development based on Locationt Quotient (LQ) analysis as a base, which is located in Rembang, Pati and Jepara. coconut coir waste production based on BK, PK and TDN as a whole is 9,537; 383.29 and 2,678.4 Tons / year and for the carrying capacity of coconut coir waste in total, it is based on BK, PK and TDN, namely 31,794; 944.32 and $8,926 \mathrm{ST} /$ year.

Conclusions: The conclusion of this research is a review of the production and land preparation in increasing coconut plants using Trend analysis which later has the potential to provide raw materials, namely in Rembang Regency.

Keywords: Coconut Potential; Complete feed; Carrying Capacity of Coconut Fiber Waste

\section{PENDAHULUAN}

Pengembangan usaha peternakan ruminansia khususnya sapi potong di Indonesia secara umum masih belum dikatakan maju, meskipun produksi daging didominasi oleh peternakan rakyat $78 \%$ dan sisanya didatangkan dari impor dalam bentuk daging 5\% dan ternak hidup 37\% [1]. Pakan merupakan salah satu faktor yang dapat mempengaruhi proses produksi dan produktivitas ternak yaitu $70 \%$ [2]. Pakan dengan kandungan nutrisi yang tinggi cenderung memiliki harga yang mahal. Salah satu upaya dalam peningkatan produktivitas dan menekan harga pakan ternak yaitu melalui pakan dengan pemanfaatan limbahlimbah pertanian, perkebunan, maupun industri. Untuk menekan biaya pakan perlu adanya suatu pemanfaatan limbah-limbah tanaman pangan guna bisa dimanfaatkan menjadi pakan ternak. Salah satu limbah yang belum banyak dimanfaatkan untuk dijadikan sebagai bahan campuran pakan yaitu limbah sabut kelapa.

Tanaman kelapa merupakan tanaman yang banyak tumbuh di Indonesia khususnya di wilayah yang dekat dengan pantai. Kabupaten Rembang, Pati, Jepara, Batang dan Pekalongan merupakan wilayah yang dekat dengan pantai dan memiliki luas lahan dan produksi kelapa yang cukup tinggi dibandingkan dengan kabupaten lainnya yang ada di jalur pantura Jawa Tengah yaitu sebesar 4.038,63; 6.088,63; 9.662,58; 3.232,68 dan 1.009, 00 /ton/tahun. Menurut Direktorat Jendral Perkebunan [3] luas lahan perkebunan kelapa di Indonesia sebanyak 3.548.883 ha dengan produksi 2.887.961 ton/tahun. Hasil samping dari buah kelapa yaitu tempurung dan sabut, dimana sabut kelapa belum banyak dimanfaatkan oleh masyarakat khususnya untuk dijadikan campuran pakan ternak ruminansia sebagai sumber serat. Menurut Tyas [4] Komposisi kimia sabut kelapa yaitu air $26 \%$, pektin $14,25 \%$, hemiselulosa $8,50 \%$, selulosa $21,07 \%$ dan lignin $29,23 \%$. Sehubungan dengan itu perlu adanya suatu pengolahan dan pemanfaatan sabut kelapa agar dapat dijadikan sebagai bahan pakan bagi ternak ruminansia, selain itu juga dapat membantu mengurangi biaya pakan dalam usaha peternakan.

Tujuan penelitian yaitu mengkaji dan menganalisis potensi dan strategi pengembangan tanaman kelapa sumber bahan baku sabut kelapa sebagai bahan pakan dalam complete feed. Mengkaji kontinyuitas ketersediaan limbah sabut kelapa sebagai pakan ruminansia. Hipotesis dalam penelitian ini yaitu potensi sabut kelapa sebagai sumber serat dalam pembuatan complete feed dapat dikembangkan dan digunakan sebagai salah satu bahan pakan alternatif sumber serat. 


\section{MATERI DAN METODE}

\section{Metode penelitian}

Metode yang digunakan dalam penelitian ini yaitu dengan menggunakan metode Survei. Penelitian ini akan dilaksanakan pada bulan Juni - Juli 2019. Lokasi penelitian yaitu menggunakan wilayah Kabupaten Rembang. Kabupaten Pati, Kabupaten Jepara dan Kabupaten Batang. Pemilihan tempat menggunakan Purposive Sampling berdasarkan luas lahan kelapa dan produksi buah kelapa (Tabel 1) dan potensi limbah sabut kelapa melimpah karna daerah tersebut dekat dengan pantai yang banyak pedagang buah kelapa.

\section{Metode pengumpulan data}

Metode yang digunakan dalam penelitian ini adalah metode survei. Data yang dikumpukan berupa data primer dan data sekunder. Data primer didapat langsung dari pedagang buah kelapa petani kelapa, masing masing wilayah diambil sebanyak 10 responden dari pedagang buah kelapa. Data sekunder didapat dari Badan Pusat Statistik (BPS) dan Dinas Perkebunan Kabupaten Rembang, Kabupaten Pati, Kabupaten Jepara, dan Kabupaten Batang. Data yang dikumpulkan dianalisis secara deskriptif.

\section{Metode analisis data}

Tabel 1. Luas areal dan produksi buah kelapa

\begin{tabular}{|c|c|c|c|c|c|c|c|}
\hline \multirow{2}{*}{ Kabupaten } & & \multicolumn{5}{|c|}{ Tahun } & \multirow{2}{*}{ Total } \\
\hline & & 2014 & 2015 & 2016 & 2017 & 2018 & \\
\hline \multirow[t]{3}{*}{ Rembang } & Luas areal (ha) & 7,151 & 7,221 & 7,554 & 7,552 & 7,552 & \\
\hline & Produksi (ton) & $4,012.00$ & $4,137.24$ & 4,039 & 4,214 & 4,214 & $20,616.24$ \\
\hline & Jumlah & & & & & & \\
\hline \multirow[t]{4}{*}{ Pati } & Luas areal & $6,315.75$ & $6,315.75$ & $6,309.75$ & $6,306.85$ & $6,049.55$ & \\
\hline & Produksi (btr) & $6,188,560$ & $6,188,560$ & $6,088,625$ & $5,858,734$ & $6,088,626$ & \\
\hline & Produksi (ton) & 4210.77 & 4210.77 & 2435.45 & 2343.49 & 2435.45 & $15,635.93$ \\
\hline & Jumlah & & & & & & \\
\hline \multirow[t]{4}{*}{ Jepara } & Luas areal & $12,656.11$ & $12,645.47$ & $12,522.74$ & $12,499.85$ & $12,451.30$ & \\
\hline & Produksi (ton) & $11,053.98$ & $11,113.94$ & $9,662.56$ & $9,765.73$ & $9,361.47$ & $50,957.68$ \\
\hline & Produksi (btr) & 7369320 & 7409293.333 & 6441706.667 & 6510486.667 & 6240980 & \\
\hline & Jumlah & & & & & & \\
\hline \multirow[t]{4}{*}{ Batang } & Luas areal & $2,599.64$ & $2,194.82$ & $2,125.76$ & $2,136.08$ & $2,038.79$ & \\
\hline & Produksi (btr) & $2,116,431$ & $6,043,820$ & $9,066,132$ & $5,814,977$ & $6,426,137$ & \\
\hline & Produksi (ton) & 846.5724 & 2417.528 & 3626.4528 & 2325.9908 & 2570.4548 & $11,787.00$ \\
\hline & Jumlah & & & & & & \\
\hline
\end{tabular}

Analisis yang digunakan dalam penelitian ini yaitu analisis Trend, Location Quotient (LQ) dan analisis SWOT. Analsisi Trend menggunakan persamaan :

$$
\begin{aligned}
& \mathrm{Y}=\mathrm{a}+\mathrm{b} \cdot \mathrm{X} 1) \\
& \mathrm{a}=\sum \mathrm{Y}+\mathrm{N} \\
& \mathrm{b}=\sum \mathrm{XY}+\mathrm{X} 2
\end{aligned}
$$

Keterangan :

$\mathrm{Y}=$ Variabel dependen

$\mathrm{X}=$ Variabel independen

b = Nilai Konstanta

a $=$ Parameter

Analisis Location Quotient (LQ) menggunakan persamaan sebagai berikut : Firman dan Nono [5]

$$
\mathrm{LQ}=\frac{\mathrm{Si} / \mathrm{S}}{\mathrm{Ni} / \mathrm{N}}
$$

Keterangan :

$\mathrm{Si}=$ Jumlah buah kelapa di wilayah kabupaten

$\mathrm{Ni}=$ Jumlah total komoditas di kabupaten

$S=J u m l a h$ total buah kelapa di kabupaten

$\mathrm{N}=$ Jumlah total komoditas di kabupaten

\section{Produksi sabut kelapa}

Produksi sabut kelapa dihitung dengan rumus sebagai berikut : 


$$
\text { Prsk }=\text { Prk } \times 0,35
$$

Keterangan :

Prsk = Produksi sabut kelapa (ton)

Prk = Produksi Kelapa (ton/ha/tahun)

0,35 = nilai sabut kelapa dalam satu butir $(35 \%)$

Konversi sabut kelapa segar ke bahan kering

$$
\mathrm{BK}=\mathrm{BS} \times 78,97 \%
$$

Keterangan :

$$
\begin{array}{ll}
\mathrm{BK} & =\text { Bahan Kering } \\
\mathrm{BS} & =\text { Berat Segar } \\
78,97 \% & =\text { Kadar BK sabut kelapa }
\end{array}
$$

\section{Daya dukung sabut kelapa}

Menghitung daya dukung sabut kelapa sebagai campuran dalam complete feed menggunakan rumus sebagai berikut Sari et al. [6] :

$$
\begin{aligned}
& \begin{array}{l}
\text { Daya dukung }= \\
\text { Produksi BK sabut kelapa }
\end{array} \\
& \hline \text { penggunaan sabut kelapa dalam formulasi }
\end{aligned}
$$

\section{Analisis SWOT}

Menurut Rangkuti [7] Terdapat delapan langkah dalam membentuk sebuah matriks SWOT, adalah sebagai berikut :

1) Membuat daftar peluang-peluang eksternal utama.

2) Membuat daftar ancaman-ancaman eksternal utama.
3) Membuat daftar kekuatan kekuatan internal utama.

4) Membuat daftar kelemahan kelemahan internal utama.

5) Mencocokkan kekuatan internal dengan peluang eksternal dan mencatat hasilnya pada sel strategi SO.

6) Mencocokkan kelemahan internal dengan peluang eksternal dan mencatat hasilnya pada sel strategi WO.

7) Mencocokkan kekuatan internal dengan ancaman eksternal dan mencatat hasilnya pada sel strategi ST.

8) Mencocokkan kelemahan internal dengan ancaman eksternal dan mencatat hasilnya pada strategi WT.

\section{HASIL DAN PEMBAHASAN}

\section{Produksi dan daya dukung limbah sabut kelapa}

Produksi limbah sabut kelapa dan daya dukung limbah sabut kelapa dapat dilihat pada Tabel 2 dan Tabel 3. Limbah pertanian sebagai pakan ternak bisa dikalkulasi berdasarkan kebutuhan bahan kering (BK), protein kasar $(\mathrm{PK})$ dan total digestible nutrients (TDN) dapat dilihat pada Tabel 4.

Produksi bahan pakan menurut BK, PK dan TDN yaitu 9.537; 283,29 dan 2.678,4 $\mathrm{kg} /$ tahun. Daya dukung limbah sabut kelapa $30 \%$ sebagai campuran dalam complete feed atau konsentrat secara keseluruhan memang belum mencukupi populasi ternak di empat

Tabel 2. Produksi limbah sabut kelapa (ton/tahun)

\begin{tabular}{clccc}
\hline No. & Kabupaten & BK (ton/tahun) & PK (ton/tahun) & TDN (ton/tahun) \\
\hline 1. & Rembang & 2.163 & 64,267 & 607,620 \\
2. & Pati & 1.250 & 37,128 & 351,036 \\
3. & Jepara & 4.805 & 142,710 & $1.349,300$ \\
4. & Batang & 1.319 & 39,186 & 370,490 \\
\hline \multicolumn{7}{c}{ Total } & 9.537 & 283,290 & $2.678,400$ \\
\hline
\end{tabular}

Tabel 3. Daya dukung limbah sabut kelapa 30\% dalam ransum

\begin{tabular}{clcccc}
\hline No. & \multicolumn{1}{c}{ Kabupaten } & $\mathrm{BK}^{*}(\mathrm{ST})$ & $\mathrm{PK}^{*}(\mathrm{ST})$ & $\mathrm{TDN}^{*}(\mathrm{ST})$ & Populasi** $^{* *}$ \\
\hline 1. & Rembang & 7.212 & 214,22 & 2.025 & 132.543 \\
2. & Pati & 4.167 & 123,76 & 1.170 & 102.701 \\
3. & Jepara & 16.017 & 475,72 & 4.497 & 44.854 \\
4. & Batang & 4.398 & 130,62 & 1.234 & 20.985 \\
\hline \multicolumn{7}{r}{ Total } & 31.7940 & 944,32 & 8.926 &
\end{tabular}

Sumber: ${ }^{* *}$ Badan Pusat Statistik, 2018 
Tabel 4. Kandungan nutrient sabut kelapa dalam 100\% BK

\begin{tabular}{lc}
\hline \multicolumn{1}{c}{ Kandungan nutrien* } & Sabut kelapa (\%) \\
\hline Bahan kering & 78,97 \\
Abu & 17,66 \\
Protein kasar & 2,62 \\
Lemak kasar & 2,87 \\
Serat kasar & 51,92 \\
BETN & 24,93 \\
TDN** & 38,19 \\
\hline Sumber: & *Hasil analisis proksimat di Laboratorium Ilmu Nutrisi dan Pakan Fakultas Peternakan dan \\
& Pertanian Universitas Diponegoro $(2018) ; *$ Hasil Perhitungan Berdasarkan Sutardi $(2001) ;$ Pakan \\
\multicolumn{2}{l}{ dengan SK $>18 \%$ dan PK $<20 \%$; TDN $=70,6+(0,259 x P K)+(1,01 x$ LK) $-(0,760 x S K)+(0,0991 \times B E T N)$}
\end{tabular}

kabupaten, akan tetapi populasi tersebut merupakan campuran dari beberapa tingkat fisiologis yang berbeda. Carrying Capacity menurut Dinas Peternakan Provinsi Jawa Tengah [8] yaitu 1 ST sama dengan 1 ekor sapi dewasa dengan berat $300 \mathrm{~kg}$ dengan konsumsi bahan kering sebanyak $8,4 \mathrm{~kg}$ per ST/Hari atau setara dengan $3066 \mathrm{~kg}$ BK/ST/tahun. Kebutuhan ternak ruminansia berdasarkan beberapa acuan. NRC [9] kebutuhan pakan ternak ruminansia (1 ST) akan bahan kering $6,25 \mathrm{~kg} / \mathrm{ST}$. Ditjen Peternakan dan Fapet UGM [10] mengkalkulasi bahwa kebutuhan pakan ternak ruminansia (1 ST) untuk protein adalah $0,66 \mathrm{~kg} / \mathrm{ST}$ dan untuk TDN adalah $4,3 \mathrm{~kg} / \mathrm{ST}$. Satu unit ternak setara dengan satu ekor sapi seberat $455 \mathrm{~kg}$ dan asumsi penggunaan limbah mencapai $30 \%$ dan $40 \%$ sebagai pakan [11] Pakan digunakan untuk kebutuhan hidup, pertumbuhan, perkembangan, dan reproduksi. Sari et al. [6], satu unit ternak adalah sama dengan seekor sapi dewasa. Daya dukung limbah sabut kelapa sebagai pakan dapat dilihat pada Lampiran 10.

Upaya pencarian sumber pakan alternatif sangat diperlukan dengan pertimbangan yang rasional, seperti murah dan mudah didapat serta tersedia sepanjang tahun guna memenuhi kebutuhan dalam pengembangan populasi ternak. Menurut Tiwow et al. [12] Kapasitas penambah populasi ternak sapi dipengaruhi oleh luas lahan pertanian, luas panen, produktivitas masing-masing komoditas, luas hutan dan populasi ternak sapi yang ada. Prasetyo et al. [13] Nilai Indeks Daya Dukung pakan (IDD) di atas 2 dikategorikan aman terdapat di 8 Kecamatan dengan nilai tertinggi berada di Kecamatan Lasem sebesar 3,8. Berdasarkan hasil analisis satuan ternak, populasi ternak sapi potong betina produktif sejumlah $81.937 \mathrm{ST}$, dimana daya tampung ternak sapi sebanyak 105.263,57 ST/tahun, apabila dikurangi dengan populasi ternak sapi potong yang ada maka potensi penambahan populasi sebesar 23.326,33 ST/tahun.

Daya dukung pakan merupakan kemampuan suatu wilayah untuk menghasilkan dan menyediakan makanan ternak yang dapat menampung kebutuhan

Tabel 5. Hasil analisis LQ potensi buah kelapa

\begin{tabular}{clccccccl}
\hline No. & Kabupaten & 2014 & 2015 & 2016 & 2017 & 2018 & Rata-Rata & Keterangan \\
\hline 1. & Rembang & 2.0 & 1.8 & 1.9 & 1.9 & 1.8 & 1.88 & Basis \\
2. & Pati & 1.7 & 1.5 & 1.2 & 1.2 & 1.3 & 1.38 & Basis \\
3. & Jepara & 2.7 & 2.2 & 2.1 & 2.3 & 2.3 & 2.32 & Basis \\
4. & Batang & 0.1 & 0.3 & 0.4 & 0.2 & 0.3 & 0.26 & Non basis \\
\hline
\end{tabular}

Tabel 6. Hasil analisis LQ potensi lahan buah kelapa

\begin{tabular}{clccccccl}
\hline No. & Kabupaten & 2014 & 2015 & 2016 & 2017 & 2018 & Rata-Rata & Keterangan \\
\hline 1. & Rembang & 1.3 & 1.3 & 1.3 & 1.3 & 1.3 & 1.30 & Basis \\
2. & Pati & 1.0 & 1.1 & 1.1 & 1.1 & 1.1 & 1.08 & Basis \\
3. & Jepara & 1.4 & 1.4 & 1.4 & 1.4 & 1.4 & 1.40 & Basis \\
4. & Batang & 0.7 & 0.6 & 0.7 & 0.6 & 0.6 & 0.64 & Non basis \\
\hline
\end{tabular}


Tabel 7. Hasil IFAS analisis faktor kekuatan

\begin{tabular}{|c|c|c|c|c|c|}
\hline No. & Faktor kekuatan & Nilai penting & BOBOT (B) & Rating (R) & Skor $(\mathrm{B}) \mathrm{x}(\mathrm{R})$ \\
\hline 1. & $\begin{array}{l}\text { Ketersediaan bahan baku yang } \\
\text { melimpah }\end{array}$ & 3,00 & 0,20 & 5,00 & 1,03 \\
\hline & $\begin{array}{l}\text { Pedikitnya pengetahuan dalam } \\
\text { penggunaan sabut kelapa sebagai } \\
\text { bahan pakan }\end{array}$ & 2,75 & 0,18 & 4,45 & 0,84 \\
\hline 3. & $\begin{array}{l}\text { Antusiasme penggunaan sabut } \\
\text { kelapa sebagai bahan pakan ternak }\end{array}$ & 3,00 & 0,20 & 5,00 & 1,03 \\
\hline & $\begin{array}{l}\text { Belum adanya pengolahan Limbah } \\
\text { sabut kelapa sebagai bahan pakan }\end{array}$ & 3,00 & 0,20 & 4,57 & 0,94 \\
\hline 5. & $\begin{array}{l}\text { Adanya dukungan pemerintah } \\
\text { daerah dalam pengembangan } \\
\text { pertanian kelapa }\end{array}$ & 2,75 & 0,18 & 5,00 & 0,94 \\
\hline & Total & 14,50 & 1,00 & & \\
\hline
\end{tabular}

sejumlah populasi ternak ruminansia tanpa melalui pengolahan. Ketersediaan pakan juga tidak lepas dari pemanfaatan lahan untuk pakan. Menurut Umela [14] 2016 menyatakan bahwa Pemanfaatan lahan didasarkan pada 1) Lahan sebagai sumber pakan ternak, 2) semua jenis lahan cocok sebagai sumber pakan, 3) pemanfaatan lahan sebagai usaha penyerasian antara peruntukan lahan dengan sistem pertanian, 4) dan hubungan antara lahan dengan ternak bersifat dinamis.

Berdasarkan hasil analisis proksimat limbah sabut kelapa dapat dilihat pada Tabel 4. Permasalahan pemanfaatan sabut kelapa sebagai alternatif bahan pakan adalah serat kasar yang tinggi yaitu 51,92\% menyebabkan kecernaannya menjadi rendah. Selain itu, kandungan protein yang rendah yaitu 2,62 menjadi kurang efektif untuk mencukupi kebutuhan ternak. Menurut Fitriani [15] menyatakan bahwa meningkatnya kandungan serat kasar akan menurunkan koefisien cerna pada pakan, karena serat kasar mengandung senyawa yang sulit dicerna, lebih lanjut Suwigyo et al. [16] menyatakan bahwa makin tua umur tanaman maka kadar serat kasarnya juga makin tinggi, ditunjukkan dengan dinding sel tanaman yang makin keras dan kuat. Kandungan serat kasar dan protein kasar sabut kelapa hampir sama dengan kandungan serat kasar pada pelepah kelapa sawit. Sianipar [17] menyatakan bahwa kandungan serat kasar limbah kelapa sawit cukup tinggi, khususnya daun dan pelepah yaitu $21,52 \%$ dan $50,94 \%$. Kandungan protein kasar daun sawit cukup baik yaitu 14,12\% sedangkan pelepah protein kasarnya sangat rendah yaitu 3,07\%. Tingkat kecernaan bahan kering pelepah dan daun kelapa sawit pada sapi mencapai $45 \%$.

Upaya yang dapat dilakukan untuk meningkatkan kualitas nutriennya adalah dengan melakukan pengolahan secara fisik dan biologi. Beberapa teknologi pakan ruminansia diantaranya cincangan hijauan, pembuatanhay, amoniasi, silase, biofermenetasi mikroba rumen, pengolahan jerami padidengan probiotik, teknologi pakan pemacu, dan pakan lengkap. Pengolahan secara fisik dilakukan dengan penggilingan untuk memperluas permukaan dan perlakuan biologis dilakukan dengan fermentasi dengan starter mikrobia serta penambahan molases dan urea untuk mengoptimalkan kinerjanya. Fermentasi dapat menurunkan serat kasar karena terjadi proses perenggangan ikatan lignohemiselulosa yang menyebabkan bahanbahan organik larut dan menghasilkan karbohidrat-karbohidrat sederhana [18]. Adanya teknologi dalam pengolahan limbah sabut kelapa diharapkan dapat meningkatkan kualitas nutrisi limbah sabut kelapa. Nurhajati dan Suprapto [19] melaporkan bahwa $200 \mathrm{~g}$ sabut kelapa yang telah difermentasi selama 7 hari dengan Actinobacillus ML-08 20\%, urea $1 \%$ dan $2 \%$ tetes dapat meningkat kualitas nutriennya yaitu protein kasar meningkat dari 4,58\% menjadi $6,83 \%$ dan menurunkan serat kasarnya dari $57,16 \%$ menjadi $47,19 \%$. 
Tabel 8. Hasil IFAS analisis faktor kelemahan

\begin{tabular}{|c|c|c|c|c|c|}
\hline No. & Faktor Kelemahan & Nilai penting & BOBOT (B) & Rating (R) & Skor $(\mathrm{B}) \mathrm{x}(\mathrm{R})$ \\
\hline 1. & $\begin{array}{l}\text { Kurangnya informasi komunikasi } \\
\text { terhadap potensi limbah sabut } \\
\text { kelapa sebagai bahan baku pakan }\end{array}$ & 2,25 & 0,13 & 4,82 & 0,65 \\
\hline 2. & $\begin{array}{l}\text { Kekurangan stok kelapa saat musim } \\
\text { hujan }\end{array}$ & 2,5 & 0,15 & 4,17 & 0,63 \\
\hline 3. & $\begin{array}{l}\text { Terbatasnya sarana dan prasarana } \\
\text { dalam pengolahan sabut kelapa }\end{array}$ & 2,75 & 0,16 & 4,85 & 0,80 \\
\hline 4. & $\begin{array}{l}\text { Lemahnya kesadaran peternak } \\
\text { rakyat dalam memanfaatkan limbah } \\
\text { sabut kelapa sebagai bahan pakan } \\
\text { sumber serat }\end{array}$ & 3,00 & 0,18 & 5,00 & 0,90 \\
\hline 5. & $\begin{array}{l}\text { Sabut kelapa memiliki nilai nutrisi } \\
\text { rendah }\end{array}$ & 2,25 & 0,15 & 5,00 & 0,75 \\
\hline 6. & $\begin{array}{l}\text { Pengolahan sabut } \\
\text { membutuhkan waktu }\end{array}$ & 2,00 & 0,12 & 4,82 & 0,58 \\
\hline 7. & $\begin{array}{l}\text { Kurangnya dukungan dana APBD } \\
\text { dalam pengembangan perkebunan } \\
\text { kelapa }\end{array}$ & 1,50 & 0,09 & 4,30 & 0,39 \\
\hline & Total & 16,50 & 1,00 & & \\
\hline
\end{tabular}

Analisis Location Quotient (LQ) dalam pengembangan tanaman kelapa

Teknik Location Quotient (LQ) merupakan teknik yang digunakan untuk membahas kegiatan ekonomi dalam mendapatkan gambaran dalam penetapan sektor unggulan sebagai suatu sektor ussaha yang dapat dikembangkan. Analisis LQ buah kelapa dan luas lahan dapat dilihat pada Tabel 5 dan Tabel 6.

Menurut Rizani [20] kriteria sektor unggulan (potensial) mempunyai koefisien LQ $>1$, dimana sektor tersebut mempunyai prospek yang baik dalam peningkatan perekonomian. Sektor yang tidak unggulan (potensial) mempunyai koefisien $\mathrm{LQ}<1$, dimana sektor tersebut tidak memiliki prospek yang baik dalam pengembangan perekonomian. Menurut Kalzum dan Jumiyati [21] Teknik Location Quotient (LQ) merupakan teknik yang digunakan untuk membahas kegiatan ekonomi dalam mendapatkan gambaran dalam penetapan sektor unggulan sebagai suatu sektor ussaha yang dapat dikembangkan. Kelebihan dari penggunaan metode LQ adalah rumusnya yang sederhana dan mudah mengaplikasikannya, kelemahan dari penggunaan metode LQ adalah (1) dituntut akurasi data yang tinggi untuk menghindari bias; (2) kriteria wilayah dan ruang lingkupnya sering tidak jelas; (3) analisis ini bersifat kaku dan hanya mengilustrasikan satu periode saja [22].

Berdasarkan Tabel 5 dan Tabel 6 dapat dilihat bahwa dari ke 4 kabupaten sebagai tempat penelitian yang menjadi basis dalam pengembangan tanaman kelapa yaitu Kabupaten Rembang, Kabupaten Pati dan Kabupaten Jepara dengan nilai rata-rata $L Q>1$ yaitu 1.88; 1.38; dan 2.32. Sedangkan yang bukan menjadi basis dalam pengembangan kelapa yaitu Kabupaten Batang dengan nilai $\mathrm{LQ}<1$ yaitu 0,26 . Ketersediaan buah kelapa ini sejalan dengan ketersediaan lahan untuk perkebunan buah kelapa. Kabupaten Rembang, Pati dan Jepara merupakan basis (LQ>1) lahan dalam pengembangan tanaman kelapa meskipun luas lahan setiap tahunnya cenderung sama. Sedangkan, Kabupaten Batang bukan merupakan basis $(\mathrm{LQ}<1)$ sebagai tempat dalam pengembangan tanaman kelapa.

Keunggulan tiga kabupaten yang menjadi basis yaitu Kab. Rembang, Kab. Pati dan Kab Jepara yaitu tersedianya lahan dan tingginya kepercayaan masyarakat akan nilai ekonomi tanaman kelapa. Kabupaten Jepara dan Rembang merupakan kabupaten yang memiliki luas lahan, produksi dan 
produktivitas yang tinggi dibandingkan dengan kabupaten pati dan batang. Luas areal perkebunan kelapa menurut BPS Kabupaten Jepara [20] yaitu $12.451,30$ ha, luas panen 10.353,51 ha dengan produksi 9.341,67 ton/tahun. Hal ini dikarenakan Kabupaten Jepara merupakan kabupaten dengan tingkat pariwisata yang lebih tinggi dibandingkan dengan kabupaten lainnya dan merupakan kabupaten yang memiliki banyak pantai dalam satu wilayah. Sedangkan, Menurut BPS Kabupaten Rembang [23] luas lahan perkebunan kelapa sebanyak 7.552 ha, dengan produksi 4.214 ton dengan tingkat produktivitas $875 \mathrm{~kg} / \mathrm{ha}$. Hal ini lebih rendah dari penelitian Ragusta et al. [24] yang menyatakan bahwa Luas perkebunan kelapa dalam secara keseluruhan di Kabupaten Tanjung Jabung Timur sebesar 58.677 ha dengan produksi sebesar 51.657 Ton dan tingkat produktivitasnya sebesar $1.150 \mathrm{Kg} / \mathrm{Ha}$. Menurut BPS Kab. Batang [25] penurunan jumlah tanaman dan lahan kelapa di sebabkan ketidak percayaan petani akan potensi ekonomi dari tanaman kelapa sehingga para petani tersebut mengalih fungsikan lahan kelapa menjadi tanaman kayu (sengon). Akan tetapi, Dinas Perkebunan Kabupaten Batang saat ini mulai mengembalikan dan mensosialisasikan serta mengembangkan tanaman kelapa sebagai basis dalam meningkatkan perekonomian masyarakat di Kabupaten Batang.

\section{Analisis trend dalam pengembangan tanaman kelapa}

Berdasarkan Gambar 1 dan Gambar 2 dapat dilihat bahwa kabupaten Rembang memiliki potensi dalam pengembangan perkebunan kelapa dengan melihat kenaikan

Tabel 9. Hasil IFAS analisis faktor peluang

\begin{tabular}{cccccc}
\hline No. & \multicolumn{1}{c}{ Faktor Kelemahan } & Nilai penting & BOBOT (B) & Rating (R) & Skor (B)x(R) \\
\hline 1. $\begin{array}{l}\text { Tersedianya teknologi dalam } \\
\text { pengolahan sabut kelapa sebagai } \\
\text { bahan pakan ternak }\end{array}$ & 2,75 & 0,19 & 4,42 & 0,85 \\
2. $\begin{array}{l}\text { Sabut kelapa dapat di jual secara } \\
\text { tunggal sebagai bahan pakan }\end{array}$ & 3,00 & 0,21 & 3,95 & 0,80 \\
3. $\begin{array}{l}\text { Sabut kelapa dapat dijadikan Sebagai } \\
\text { pakan berserat }\end{array}$ & 3,00 & 0,21 & 4,65 & 0,97 \\
4. Sabut kelapa dapat dijadikan pakan \\
$\begin{array}{l}\text { alternatif saat musim kemarau } \\
\text { Adanya perusahaan pakan dalam } \\
\text { memanfaatkan sabut kelapa }\end{array}$ & 2,75 & 0,19 & 4,17 & 0,83 \\
\hline \multicolumn{1}{c}{ Total } & 14,25 & 0,19 & 4,17 & 0,80 \\
\hline
\end{tabular}

Tabel 10. Hasil IFAS analisis factor ancaman

\begin{tabular}{|c|c|c|c|c|c|}
\hline No. & Faktor Kelemahan & Nilai penting & BOBOT (B) & Rating (R) & Skor $(B) x(R)$ \\
\hline 1. & $\begin{array}{l}\text { Limbah bersaing dengan produsen } \\
\text { perkakas }\end{array}$ & 1,25 & 0,11 & 4,7 & 0,55 \\
\hline 2. & $\begin{array}{l}\text { Adanya biaya dalam pengolahan } \\
\text { sabut kelapa sebagai bahan baku } \\
\text { pakan }\end{array}$ & 2,75 & 0,26 & 4 & 1,04 \\
\hline 3. & $\begin{array}{l}\text { perkebunan kelapa berkurang akibat } \\
\text { pengalihan lahan atau pengalihan } \\
\text { tanaman perkebunan }\end{array}$ & 2,25 & 0,21 & 4,57 & 0,97 \\
\hline 4. & $\begin{array}{l}\text { Minimnya produsen pengolah sabut } \\
\text { kelapa }\end{array}$ & 3,00 & 0,28 & 4,30 & 1,22 \\
\hline 5. & $\begin{array}{l}\text { Terbatasnya keinginan masyarakat } \\
\text { dalam penggunaan sabut kelapa } \\
\text { sebagai pakan ternak }\end{array}$ & 1,25 & 0,11 & 4,45 & 0,52 \\
\hline & Total & 10,50 & 1,00 & & \\
\hline
\end{tabular}


Produksi

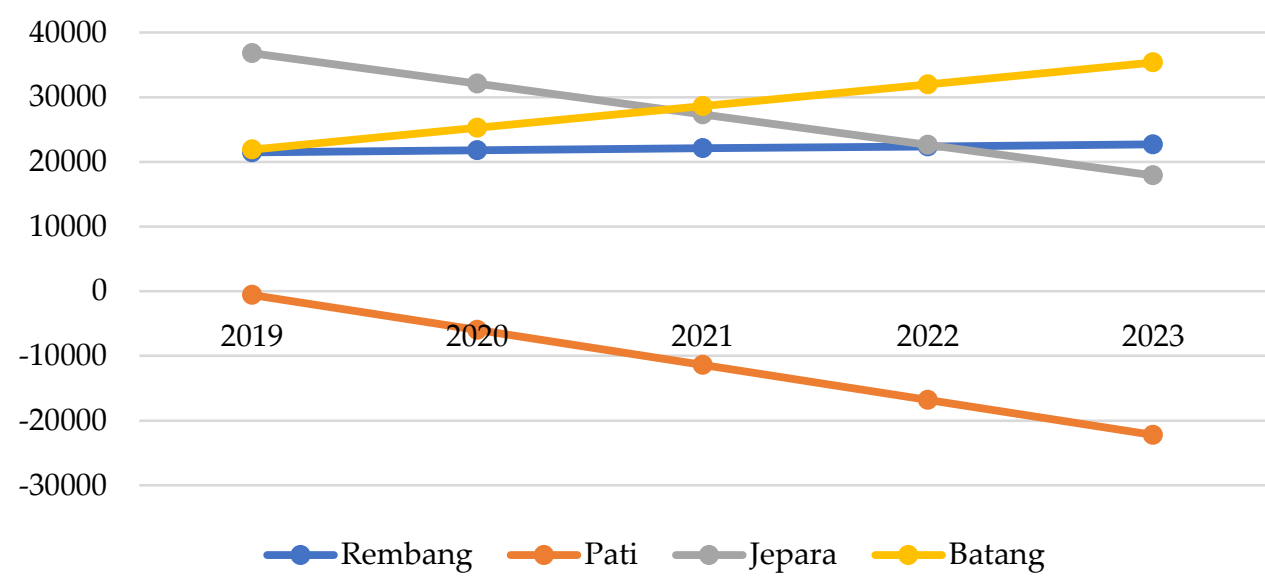

Gambar 1. Hasil analisis trend luas perkebunan tanaman kelapa

Lahan

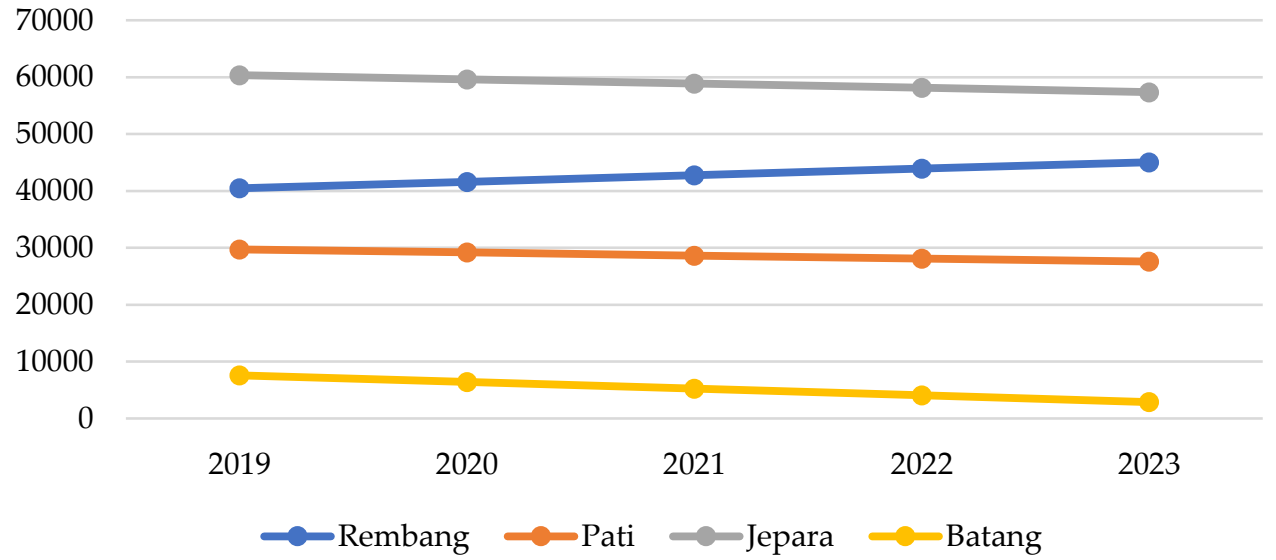

Gambar 2. Hasil analisis trend luas perkebunan tanaman kelapa

setiap tahunnya baik dalam segi produksi maupun ketersediaan lahan tanaman kelapa.

Kabupaten Batang memiliki potensi dalam pengembangan tanaman kelapa yang dapat dilihat dengan kenaikkan luas lahan, akan tetapi, kenaiakan luas lahan ini tidak sebanding dengan produksi yang terus menurun. Menurunnya produksi buah kelapa di Kabupaten Batang yaitu di sebabkan alih fungsi tanaman dari tanaman kelapa menjadi tanaman kayu, waktu peremajaan yang cukup lama, banyaknya hama tanaman yang merusak dan ketidak percayaan masyarakat akan hasil ekonomi buah kelapa. Menurut Ahungwa et al. [26] berpendapat bahwa kontribusi potensi pertanian merupakan salah satu pendorong pertumbuhan ekonomi dan pertanian pembangunan merupakan syarat dalam proses industrialisasi.

Kabupaten Rembang memiliki potensi dalam pengembangan perkebunan kelapa dengan melihat kenaikan setiap tahunnya baik dalam segi produksi maupun ketersediaan lahan tanaman kelapa. Pengambilan keputusan untuk strategi di masa yang akan datang sangat dipengaruhi oleh penyajian data yang real time melalui proses analisis metode time series. Metode time series (deret berkala atau runtut waktu) adalah metode yang digunakan untuk meramalkan waktu yang akan datang terkait hasil produksi pertanian pada tahun berikutnya. Dengan menggunakan alat analisis Trend ini, dapat pula diramalkan 
kondisi perkembangan perkebunan kelapa selama beberapa tahun kedepannya Putri [27].

Pengambilan strategi pemanfaatan limbah sabut kelapa sebagai campuran atau bahan pakan sumber serat

\section{Skor IFAS faktor kekuatan}

Berdasarkan hasil penelitian, bahwa skor tertinggi hasil IFAS pada analisis faktor kekuatan Tabel 7 adalah ketersediaan bahan baku limbah kelapa yang melimpah dengan skor 1,03. Pedagang buah kelapa merupakan salah satu produsen dalam penyediaan bahan baku dan berdampak besar pada ketersediaan limbah sabut kelapa. Berdasarkan wawancara dengan pedagang kelapa di Kabupaten Rembang, Kabupaten Pati, Kabupaten Jepara dan Kabupaten Batang, setiap pedagang buah kelapa dalam satu minggu dapat menghabiskan buah kelapa berbeda-beda dan limbah yang dihasilkan berbeda-beda pula.Pedagang buah kelapa di Kabupaten Rembang rata-rata dalam satu minggu menghabiskan 100 sampai 200 butir, Kabupaten Pati 30 sampai 50 butir, Kabupaten Jepara 150 sampai 250 butir dan Kabupaten Batang 100 sampai 150 butir, yang artinya limbah sabut kelapa basah yang dihasilakan di Kabupaten Rembang sebanyak $140 \mathrm{~kg}$, Kabupaten Jepara 175 kg, Kabupaten Batang $105 \mathrm{~kg}$ dan Kabupaten Pati $35 \mathrm{~kg}$. Selain tersedianya bahan baku yang melimpah, juga didukung dengan tingginya antusiasme masyarakat dan peternak dalam memanfaatkan limbah sabut kelapa sebagai bahan pakan dengan skor 1.03.

\section{Skor IFAS faktor kelemahan}

Berdasarkan hasil penelitian bahwa skor tertinggi hasil IFAS pada analisis faktor kelemahan Tabel 8 yaitu lemahnya kesadaran masyarakat dan peternak rakyat dalam memanfaatkan limbah sabut kelapa sebagai bahan pakan sumber serat dengan skor 0,90. Rendahnya pengetahuan peternak dalam memanfaatkan limbah sabut kelapa sebagai pakan ternak yaitu belum adanya atau masih jarang penelitian penggunaan limbah sabut kelapa sebagai pakan dan kurangnya sosialisasi penyuluh lapangan dalam memberikan informasi dalam memanfaatkan limbah tersebut. Selain kurangnya informasi limbah sabut kelapa memiliki nilai nutrisi yang rendah sehingga masih membutuhkan proses dalam pengembangan limbah ini. Selain itu kelemahan lainya adalah terbatasnya sarana dan prasarana dalam pengolahan limbah sabut kelapa sebagai bahan pakan dengan skor 0,80. Salah satu kelemahan dalam pemanfaatan limbah sabut kelapa yaitu pengolahan yang sedikit sulit dibandingkan dengan limbah-limbah pertanian seperti jerami padi. Akan tetapi sudah bnayak produsen dalam pengolahan sabut kelapa menjadi serbuk sabut kelapa meskipun pembuatanya di prioritaskan untuk media tanam.

\section{Skor EFAS faktor peluang}

Berdasarkan hasil penelitian bahwa skor tertinggi hasil EFAS analisis faktor peluang Tabel 9 yaitu limbah sabut kelapa dapat di olah dan dijadikan sebagai bahan pakan sumber serat dengan skor 0,97 dan tersedianya teknologi dalam pengolahan limbah sabut kelapa untuk dijadikan sebagai bahan pakan ternak dengan skor 0,85 . Salah satu teknologi dalam pengolahan limbah sabut kelapa yaitu dengan teknologi fermentasi dan amoniasi. Teknologi ini sudah banyak dilakukan oleh peternak karena relatif lebih mudah di aplikasikan. Limbah sabut kelapa merupakan limbah perkebunan yang

Tabel 11. Hasil skoring faktor internal dan faktor eksternal

\begin{tabular}{clcc}
\hline No. & \multicolumn{1}{c}{ Kriteria } & Skor & Koordinat \\
\hline & Faktor Internal & & \\
1. & Kekuatan & 14,50 & $\mathrm{X}=-2$ \\
2. & Kelemahan & 16,60 & \\
& Faktor Eksternal & & $\mathrm{Y}=3,75$ \\
1. & Peluang & 14,25 & \\
2. & Ancaman & 10,50 & \\
\hline
\end{tabular}


Tabel 12. Pengambilan keputusan strategi pengembangan limbah sabut kelapa sebagai pakan

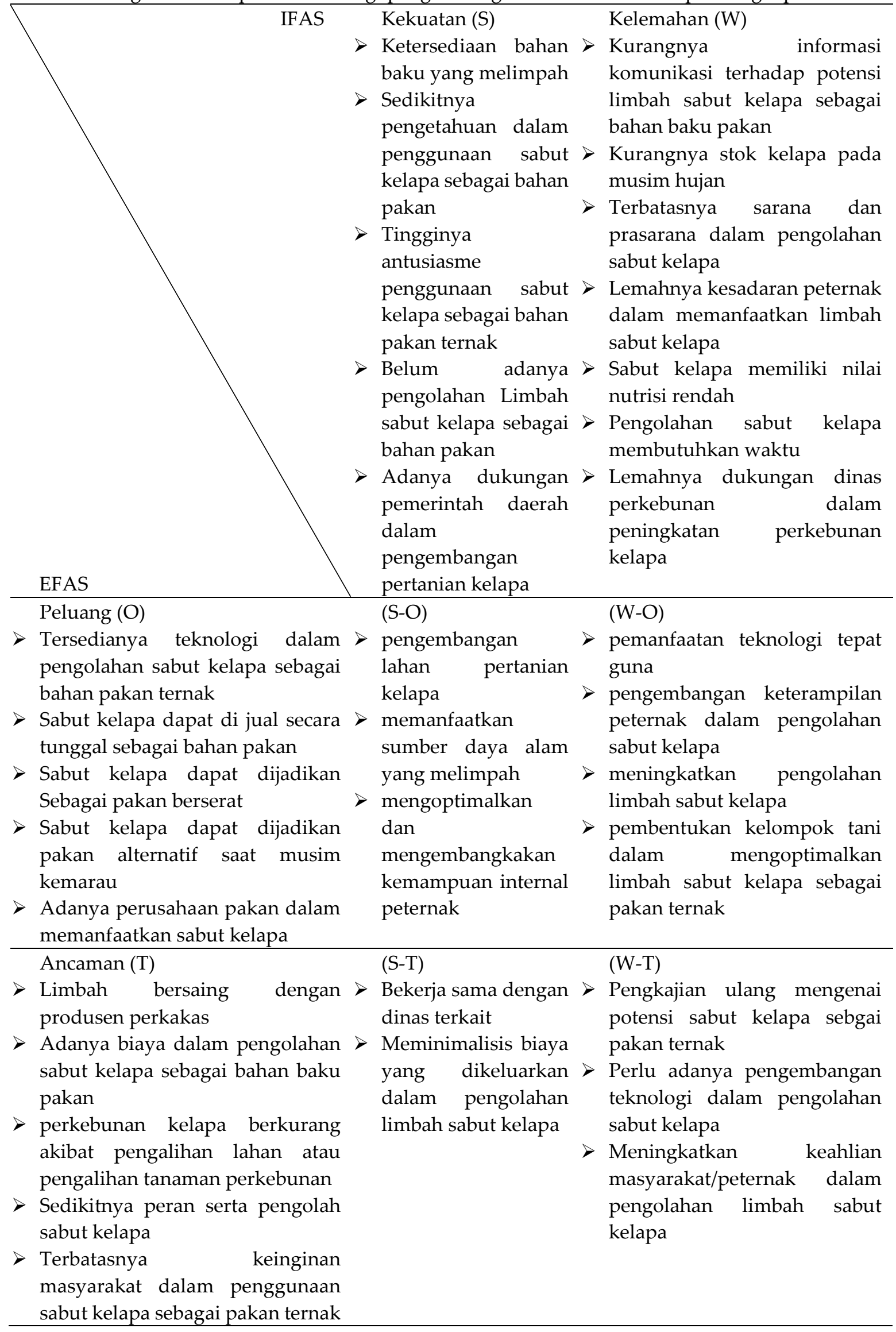


memiliki nilai nutrisi yang rendah Tabel 4 . Teknologi fermentasi dan amoniasi bertujuan untuk meningkatkan kualitas nutrisi limbah sabut kelapa menjadi lebih baik. Menurut Nurhajati dan Suprapto [28] melaporkan bahwa $200 \mathrm{~g}$ sabut kelapa yang telah difermentasi selama 7 hari dengan Actinobacillus ML-08 20\%, urea 1\% dan 2\% tetes dapat meningkat kualitas nutriennya yaitu protein kasar meningkat dari $4,58 \%$ menjadi $6,83 \%$ dan menurunkan serat kasarnya dari $57,16 \%$ menjadi $47,19 \%$. Limbah sabut kelapa yang sudah diolah dapat dialikasikan baik sebagai pakan sumber serat atau menjadi campuran dalam complete feed dan konsentrat Limbah sabut kelapa selain ketersediaanya cukup melimpah juga merupakan salah satu alternatif pakan yang dapat diberikan pada saat musim kemarau dimana hijauan pakan kurang tersedia.

\section{Skor EFAS faktor ancaman}

Berdasarkan hasil penelitian skor tertinggi hasil EFAS analisis faktor ancaman Tabel 10 yaitu masih sedikitnya produsen pengolahan limbah sabut kelapa dengan nilai 1,22. Produsen pengolahan sabut kelapa secara komersial masih jarang ditemukan hal ini dikarenakan kebutuhan akan sabut kelapa masih sedikit. Sabut kelapa rata-rata hanya digunakan sebagai alat grabah seperti sabu keset dan juga dijadikan sebagai media tanam contohnya untuk tanaman angrek. Dengan adanya suatu inovasi penggunaan limbah sabut kelapa sebagai pakan ternak diharapkan mampu mendorong para pelaku usaha untuk memajukan dan mengembangkan pengolahan limbah sabut kelapa sehingga kontinyuitas dapat berlangsung. Kiloes et al. [29] pengembangan limbah sabut kelapa sebagai pakan ternak perlu adanya dukungan dari para pelaku usaha maupun peternak, dan kebijakan pemerintah dengan melakukan promosi dan penyampaian informasi yang relevan kepada para pelaku usaha. Ancaman lainya yaitu pengalihan fungsi lahan yang terus berkembang yang mengakibatkan berkurngnya lahan kelapa yang dapat mengakibatkan dan berpengaruh pada ketersediaan bahan baku limbah sabut kelapa. Selain itu, pengolahan limbah sabut kelapa membutuhkan biaya yang lebih dibandingkan dengan pengolahan limbah perkebunan lainnya. Biaya yang diperlukan dalam pengolahan limbah sabut kelapa dalam hal ini

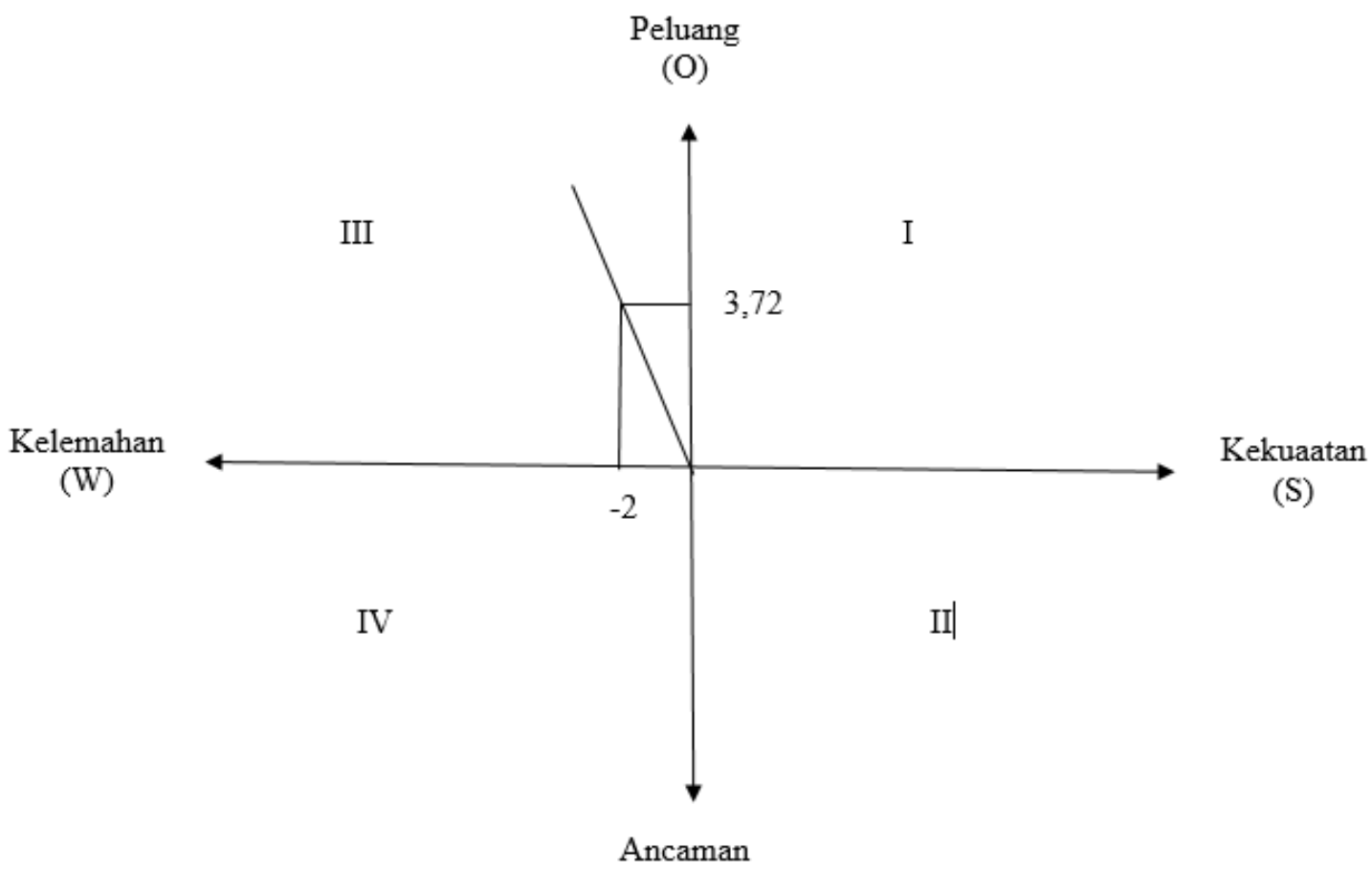

(T)

Gambar 3. Diagram analisis SWOT pengembangan limbah sabut kelapa sebagai pakan 
fermentasi yaitu membutukan tempat dan bahan-bahan dengan kualitas yang baik. Kualitas yang baik tentunya memiliki harga yang cukup mahal.

\section{Penentuan posisi potensi limbah sabut kelapa sebagai campuran Complete Feed}

Hasil skoring faktor internal dan faktor eksternal terhadap potensi Limbah sabut kelapa sebagai campuran pada Complete feed atau konsentrat dapat dilihat pada Tabel 11 dan Gambar 3.

Berdasarkan Gambar 3 diketahui bahwa potensi limbah sabut kelapa sebagai pakan ternak berada pada kuadran III yang artinya limbah sabut kelapa memiliki peluang untuk dijadikan sebagai campuran pada Complete feed, akan tetapi bahak menghadapi kendala dan kelemahan-kelemahan internal. Selisih antara kekuatan dan kelemahan adalah -2 dan selisih antara peluang dan ancaman menunjukkan angka 3,72. Kuadran III menunjukan bahwa suatu perusahaan harus menggunakan strategi turn-around dimana harus dipikirkan kembali mengenai penggunaan limbah sabut kelapa sebagai pakan ternak dengan meminimalkan kelemahan-kelemahan yang ada. Menurut Rangkuti [7] kuadran III merupakan kuadran yang memposisikan perusahaan dalam menghadapi peluang pasar yang sangat besar, akan tetapi, terdapat pada pihak lain serta menghadapi berbagai kendala atau kelemahan internal, sehingga fokus strategi ini adalah dengan meminimalkan masalahmasalah internal agar dapat memiliki peluang pasar yang lebih baik. Keempat strategi dalam analisis SWOT merupakan acuan utama dalam perumusan indikator kinerja utama yang merupakan suatu ukuran atau indikator yang akan memberikan informasi sejauh mana keberhasilan pencapaian kinerja terhadap sasaran strategis yang telah ditetapkan suatu organisasi atau perusahaan dalam mencapai tujuannya [27].

\section{KESIMPULAN}

Hasil penelitian dapat disimpulkan bahwa penggunaan limbah sabut kelapa sebagai pakan ternak memiliki potensi yang dapat dikembangkan menggunakan strategi pada analisis SWOT yaitu memanfaatkan sumberdaya alam yang melimpah, meningkatkan kemampuan peternak dan memanfaatkan teknologi yang tepat guna. Pengembangan lahan tanaman kelapa berdasarkan analisis Location Quotient (LQ) sebagai basis yaitu berada di Kabupaten Rembang, Pati dan Jepara. Daya dukung limbah sabut kelapa secara keseluruhan dapat mencukupi kebutuhan BK 31.794 ST, PK 944,32 ST dan TDN 8.926 ST. Peninjauan dalam produksi dan sediaan lahan dalam peningkatan tanaman kelapa menggunakan analisis Trend yang nantinya berpotensi menyediakan bahan baku yaitu berada pada Kabupaten Rembang.

\section{KONFLIK KEPENTINGAN}

Penulis tidak ada konflik kepentingan dengan organisasi keuangan manapun terkait materi dalam naskah. Kepentingan dalam naskah ini adalah untuk memberikan informasi kepada pelaku peternakan dalam pengembangan pengolahan pakan. Tidak ada peran penyandang dana dalam penelitian ini baik untuk desain studi, dalam pengumpulan, analisis, atau interpretasi data dalam penulisan naskah, atau dalam keputusan untuk menerbitkan hasilnya.

\section{UCAPAN TERIMA KASIH}

Penulis mengucapkan terimaksih yang setinggi-tingginya kepada Fakultas Peternakan Dan pertanian, Universitas Diponegoro, Badan Pusat Statistik Kabupaten Rembang, Kabupaten Pati, Kabupaten Jepara dan Kabupaten Batang.

\section{DAFTAR PUSTAKA}

1. Zakiah., A. Saleh, dan K. Matindas. 2017. Gaya kepemimpinan dan perilaku komunikasi GPPT dengan kapasitas kelembagaan sekolah peternakan rakyat di Kabupaten Muara Enim. Jurnal Penyuluhan, September 2017. 13. 2-8

2. Yenni, Y., dan A. E. Susanti.2016. Potensi Dan Pemanfaatan Hasil. Samping Tanaman Pangan Sebagai Pakan Ternak 
Ruminansia. Prosiding Seminar Nasional Lahan Suboptimal ISBN: 979-587-659-7

3. Direktorat Jendral Perkebunan. 2015. Luas Lahan dan Produksi Kelapa Nasional.

4. Tyas, S. I. S. 2000. Studi Netralisasi Limbah Serbuk Sabut Kelapa (Cocopeat) Sebagai Media Tanam. Bogor: Institut Pertanian Bogor, Fakultas Kehutanan.

5. Firman, A., dan O. H. Nono. 2020. Penentuan wilayah-wilayah sentra pengembangan ternak kecil di provinsi nusa tenggara timur. Jurnal Ilmu-ilmu Sosial dan Humaniora. 22: $64-71$

6. Sari, A., Liman., dan Muhtarudin. 2016. Potensi daya dukung limbah tanaman palawija sebagai pakan ruminansia di Kabupaten Pringsewu. Jurnal Ilmiah Peternakan Terpadu 4:100-107

7. Rangkuti, F. 2013. Analisis SWOT Teknik Membedah Kasus Bisnis. PT Gramedia Pustaka Utama. Jakarta.

8. Dinas Peternakan Provinsi Jawa Tengah. 2015. Kebutuhan Hijauan Makanan Ternak Sapi potong

9. National Research Council. 1984. Nutrient Requirement of Beef Cattle. 6th rev.ed. Washington DC: National Academy Press.

10. Ditjen Peternakan dan Fakultas Peternakan UGM. 1982. Inventarisasi Limbah Pertanian. Kerjasama Ditjen Peternakan dan Fakultas Peternakan UGM. UGM, Yogyakarta

11.Santoso, U. 1995. Tata laksana Pemeliharaan Ternak Sapi. Penebar Swadaya. Jakarta.

12. Tiwow, A. H. L., V. V. J. Panelewen, dan Arie. 2016. Analisis potensi daya dukung lahan untuk pengembangan sapi potong di kawasan Pakakaan Kabupaten Minahasa. Jurnal Zootek. 2 : 476 - 486

13. Prasetyo, A., H. Kurnianto, dan R. N. Hayati. 2020. Analisis potensi daya dukung pakan untuk pengembangan sapi potong di Kabupaten Rembang. Balai Pengkajian Teknologi Pertanian Jawa Tengah. Prosiding 412-416.

14. Umela, S., dan Nurfitriyanti Bulontio. 2016. Daya dukung jerami jagung sebagai pakan ternak sapi potong. Jtech $4: 64-72$.

15. Fitriani. 2017. Kandungan protein kasar dan serat kasar pakan komplit berbasis tongkol jagung dengan penambahan Azolla sebagai pakan ruminansia. Jurnal Galung Tropika. 6: 12-18.

16. Suwignyo, B., M. Harjono, dan R. Utomo. 2014. Pengaruh perbedaan fase silvopastural pada produksi dan komposisi kimia sorgum di Gunung Kidul Yogyakarta. Buletin Peternakan. 38: 95-100.

17. Sianipar, T. P. 2009. Efek Pelepah Daun Kelapa Sawit dan Limbah Industrinya sebagai Pakan terhadap Pertumbuhan Sapi Peranakan Ongole Pada Fase Pertumbuhan. Skripsi. Fakultas Pertanian, Universitas Sumatera Utara, Medan.

18. Fariani, A., dan S. Akhadiarto. 2009. Respon penambahan Effective Microorganism-4 (EM-4) terhadap kualitas nutrisi fermentasi limbah bagasse tebu untuk pakan ternak. Jurnal Teknologi Lingkungan. 10: 241-248.

19. Nurhajati, T., dan T. Suprapto. 2013. Penurunan serat kasar dan peningkatan protein kasar sabut kelapa (Cocos nucifera Linn) secara amofer dengan bakteri selulolitik (Actinobacillus ML-08) dalam pemanfaatan limbah pasar sebagai sumber bahan pakan. Jurnal Agroveteriner. 2: 6070.

20. Rizani, A. 2017. Analisis potensi ekonomi di sektor dan subsektor pertanian, kehutanan dan perikanan Kabupaten Jember. Jurnal Ekonomi Pembangunan. Vol. 15:137-156.

21. Firman, A., dan O. H. Nono. 2020. Penentuan wilayah-wilayah sentra pengembangan ternak kecil di provinsi nusa tenggara timur. Jurnal Ilmu-ilmu Sosial dan Humaniora. 22: 64 - 71.

22. Badan Pusat Statistik Kabupaten Jepara. 2018. Luas Areal dan Produksi Tanaman Perkebunan

23. Badan Pusat Statistik Kabupaten Rembang. 2018. Luas Areal dan Produksi Tanaman Perkebunan

24. Ragusta, R., A. Mara, dan R. Ningsih. 2013. Analisis ekonomi perkebunan kelapa dalam terhadap perekonomian wilayah Kabupaten Tanjung Jabung Timur. Jurnal Ilmiah Sosio-Ekonomi Bisnis. 16: 25-35.

25. Badan Pusat Statistik Kabupaten Batang. 2018. Luas Areal dan Produksi Tanaman Perkebunan.

26. Ahungwa, G. T., U. Haruna, and Y. A. 
Rakiya. 2014. Trend analysis of the contobution of agriculture to the gross domestic product of Nigeria. IOSR Journal of Agriculture and Veterinary Science. 7: 50-55.

27. Putri, Z, R. 2015. Analisa penyebab alih fungsi lahan pertanian ke lanahan non pertanian kabupaten/kota di provinsi Jawa Tengan 2003- 2013. Eko-Regional, Vol. 10: 17-22.
28. Kiloes, A. M., A. L. Sayekti., dan S. M. J. Anwarudin. 2015. Evaluasi Daya Saing Komoditas Kentang di Sentra Produksi Pangalengan Kabupaten Bandung. Jurnal Hortikultura. 25: 88-96.

29. Silvia, H., M, Syamsun., dan L. Kartika. 2015. Analisis strategi peningkatan daya saing komoditas kentang di kabupaten karo, Sumatera Utara. Jurnal Ilmu Pertanian Indonesia. 20: 164-170. 